\title{
Antarctic Dry Valley mineral soils contain unexpectedly high levels of microbial biomass
}

\section{Don A. Cowan, Nick J. Russell, Adam Mamais, Devon M. Sheppard}

\begin{abstract}
We have applied bioluminescent ATP detection methods to microbial enumeration in Antarctic Dry Valley mineral soils, and validated our ATP data by two independent methods. We have demonstrated that ATP measurement is a valid means of determining microbial biomass in such sites, and that the desiccated surface mineral soils of the Antarctic Dry Valleys contain cell numbers over four orders of magnitude higher than previously suggested.
\end{abstract}

Key words Antarctic Dry Valleys; Antarctica ; ATP measurement ; Bioluminescence ; Microbial biomass; Ornithogenic soils

The authors dedicate this paper to David Wynn-Williams, a friend, collaborator, and colleague, who contributed so much to Antarctic microbiology, and who was tragically killed in a road accident in March 2002.

\section{Introduction}

The Dry Valley deserts of Eastern Antarctica have long been used as analogs of planetary extremes, first for lunar and latterly for Martian exploration (McKay 1993; Andersen et al. 1990; Friedmann 1993a). These cold deserts are widely acknowledged to be the harshest arid environments on Earth and, although once considered to be inimical to life (e.g., Boyd et al. 1996), are now generally considered to support low microbiological populations (Cameron et al. 1970; Vishniac and Mainzer 1972; Vincent 1988; Wynn-Williams 1990; McKay 1993; Friedmann 1993b; Vishniac 1993) . In comparison, nutrient- and water-rich Antarctic "ornithogenic" and fellfield soils give vastly higher microbial counts (Ramsey and Stannard 1986; Wynn-Williams 1990). Dry Valley microclimatology is dominated by extreme aridity [water contents as low as $0.3 \mathrm{~g} \%$ (Vincent 1988)] resulting from low precipitation and atmospheric humidity, and low but widely fluctuating seasonal and diurnal temperatures (Vincent 1988; Thompson et al. 1971). Soil water activity may be reduced further by very high levels of salinity (Claridge and Campbell 1977). High incident solar radiation (Smith et al. 1992) and low substrate-carbon levels (Vishniac 1993) may also be significant stress factors for surface soil microbiota.

ATP analysis has been used to measure soil microbial activity (Paul and Johnson 1977) and microbial biomass (Jenkinson et al. 1979). Although the technique has suffered from the vagaries of the ATP extraction procedures (Sparling and Eiland 1983) and possible variations in cellular ATP content (Fairbanks et al. 1984), the recent development of efficient lysis reagents produced and marketed for the food industry (Siragusa et al. 1996; Davidson et al. 1999; Zwartkruis et al. 1999) offers improved sensitivity and assay reliability. 
We have applied this method, therefore, to the surface mineral soils of the Antarctic Dry Valleys and, in contradiction to previously published studies, have found relatively much higher microbial numbers.

\section{Materials and methods}

\section{Field sites}

Samples and in situ ATP analysis data were obtained from the vicinity of the Antarctic Dry Valleys of the Ross Dependency during the 1998/1999 and 1999/2000 austral summers, over a period of 21 days in January 1999 and 2000. Sites sampled included the ornithogenic soils of the Adelie penguin colony at Cape Bird, Ross Island $\left(77^{\circ} 13^{\prime} \mathrm{S}, 166^{\circ} 27^{\prime} \mathrm{E}\right)$, the western (upper) regions of the Miers Valley $\left(78^{\circ} 06^{\prime} \mathrm{S}, 163^{\circ} 48^{\prime} \mathrm{E}\right)$ and the Canada Glacier Site of Special Scientific Interest at Lake Fryxell, Taylor Valley $\left(77^{\circ} 37.1^{\prime} S\right.$, $\left.163^{\circ} 02.7^{\prime} \mathrm{E}\right)$.

\section{Sampling methods}

Samples were recovered by sterile transfer of surface $(02 \mathrm{~cm})$ and subsurface $(2-30 \mathrm{~cm})$ samples to sterile $15-\mathrm{ml}$ and $50-\mathrm{ml}$ plastic Greiner vessels, $90-\mathrm{ml}$ wide-mouthed Kartell bottles, and $250-\mathrm{ml}$ wide-mouthed Nalgene vessels. All samples were maintained at ambient temperature $\left(0^{\circ} \pm 3^{\circ} \mathrm{C}\right)$ prior to ATP analysis (typically, within 5-30 min of sampling). Samples returned to the UK for subsequent analyses were maintained at below $0^{\circ} \mathrm{C}$ (typically $-20^{\circ} \mathrm{C}$ ) during transport and storage.

\section{Environmental parameters}

Soil, water, and atmospheric temperatures were monitored with a Solomat 520c digital thermometer equipped with a $10-\mathrm{cm}$ steel probe.

\section{ATP analysis}

ATP concentrations were determined using the commercially available luminometric assay system designed to operate with the systemSURE Y2 K portable hygiene monitor (Celsis Instruments, Cambridge, UK). The monitor was powered by a $2 \mathrm{~kW}$ Honda generator. Reagents (systemSURE swabbing (lysis) solution, luciferase enzyme buffer, and lyophilized luciferase enzyme), and consumables (sterile swabs, ATP-free Rohre tubes, ventilation caps, and ATP-free Rainin pipette tips) were obtained from Celsis Instruments, Cambridge, UK. The assay procedure was performed as per the manufacturer's instructions. Reaction and reagent temperatures were maintained at $15^{\circ} \mathrm{C} \pm 3^{\circ} \mathrm{C}$. All ATP analyses were performed in triplicate or quadruplicate with appropriate control and blank analyses, and compared with a standard curve generated using $\mathrm{Na}_{2}$. ATP solutions in the range of $0.3 \mathrm{ng} \mathrm{ml}^{-1}$ to $0.3 \mu \mathrm{gml}^{-1}$. 


\section{Polar lipid fatty acid (PLFA) analysis}

The fatty acid content of soil samples $(1 \mathrm{~g})$ was determined by capillary gas chromatography analysis of fatty acid methyl esters (FAMEs), formed from polar lipids extracted from soil using the Bligh and Dyer method as described by White et al. (2000).

\section{Moisture content}

Duplicate $1 \mathrm{~g}$ soil samples were weighed and incubated at $80^{\circ} \mathrm{C}$. Samples were reweighed at 24 and $48 \mathrm{~h}$ to constant weight.

\section{DNA content}

Total DNA was recovered using materials and protocols supplied with the FastDNA SPIN Kit (BIO 101, Vista, CA, USA). Soil samples $(0.5 \mathrm{~g})$ were suspended in the buffers provided, reciprocated at high speed for $30 \mathrm{~s}$, and centri-fuged $(14,000 \mathrm{~g}$ for $5 \mathrm{~min})$ to clarify the supernatant. Supernatant fractions were further purified by adsorption to the BIO 101 binding matrix suspension under the conditions specified in the protocol. Aliquots of the eluted DNA were diluted as necessary in TE buffer $(10 \mathrm{mM}$ Tris-Cl, $2 \mathrm{mM}$ EDTA, pH 7.5) and assayed using the PicoGreen method (Molecular Probes, Eugene, OR, USA).

\section{ATP stability}

As a standard, $7.5 \mathrm{mg}$ of $\mathrm{Na}_{2}$. ATP (Sigma Chemical Company, Poole, UK) was dissolved in $50 \mathrm{ml} \mathrm{dH}_{2} \mathrm{O}$ to generate a $0.27-\mathrm{mM}$ stock solution. Samples $(20 \mathrm{ml})$ of freshly collected surface $(0-2 \mathrm{~cm})$ gravels (approximately $20 \mathrm{~g}$ ) in 50-ml Greiner tubes were supplemented with $400 \mid 1$ volumes of stock ATP solution (or other volumes as specified). Samples were agitated vigorously for $5 \mathrm{~min}$ to ensure homogeneity. All samples were assayed for ATP content using the Celsis systemSURE method (see above) prior to addition of exogenous ATP, immediately after homogeniza-tion, and subsequently at intervals over 12-40 h periods. Between assays, sample vials were repositioned in the vicinity of the sampling sites, the depth and orientation of the samples were designed to mimic, as far as possible, the original location.

\section{Results}

\section{Environmental ATP analyses}

We investigated the in situ ATP content of samples from a variety of different terrestrial biotopes in the Ross Dependency region, Eastern Antarctica, where variations in temperature, nutrient status, and water content (Table 1) are expected to introduce wide variations in the in situ microbial activity and biomass levels. Samples tested in situ included desiccated surface mineral soils, subsurface soils and permafrost, moss/lichen beds from moist "flush" areas, growing and degrading lakeside algal detritus, and ornitho-genic soils from an Adelie Penguin colony (Fig. 1, Table 1). Highest bioluminescence assay values (expressed as Relative Luminosity Units, RLU) were obtained from samples taken from or immediately underlying sites showing visible evidence of actively growing biomass (moss beds, algal mats). These values 
may well be elevated due to the presence of eukaryotic cells (see below). Desiccated surface mineral soils showed lower but highly significant values, while the lowest value was obtained from a permafrost sample.

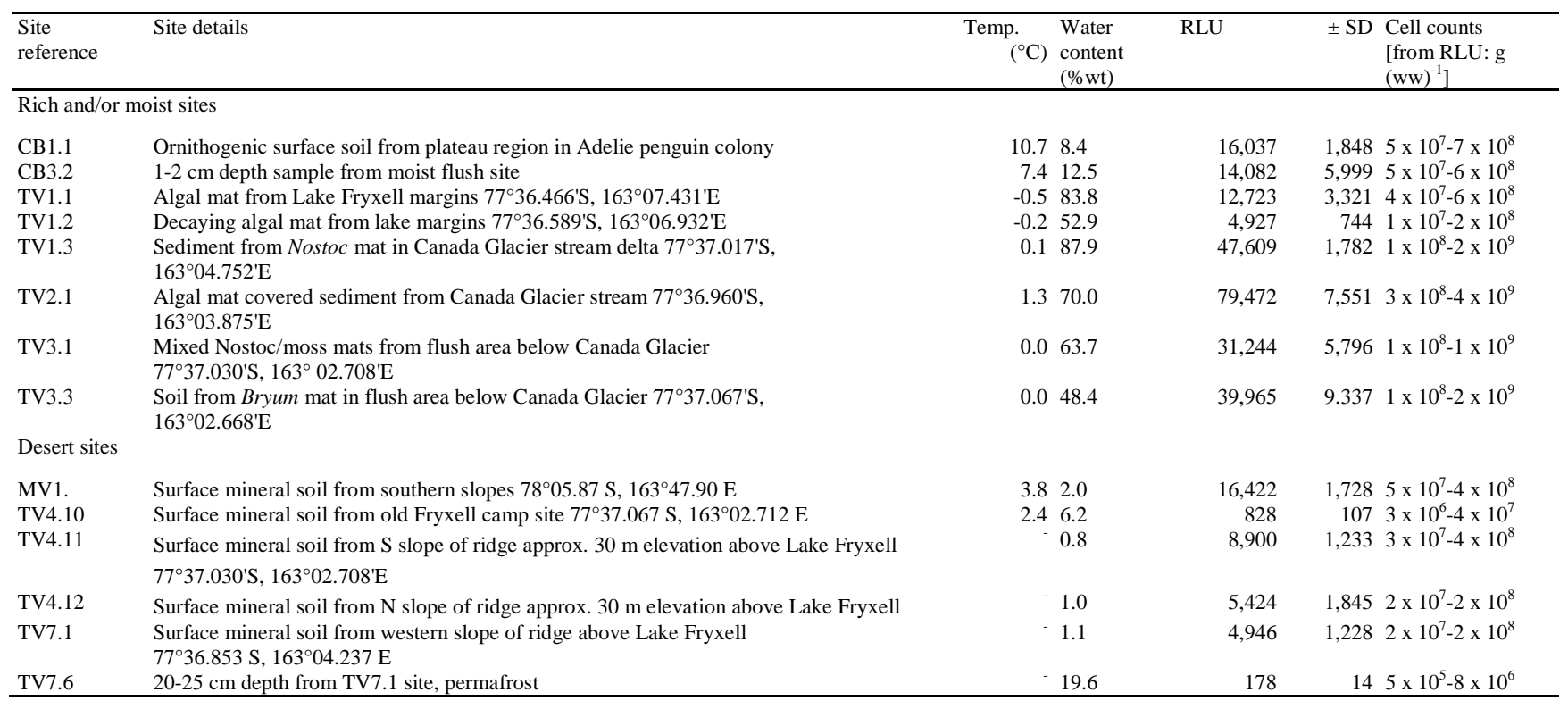

Site references are Cape Bird (CB), Taylor Valley (TV), and Miers Valley (MV)

Table 1. Physical and microbiological characteristics of sample sites
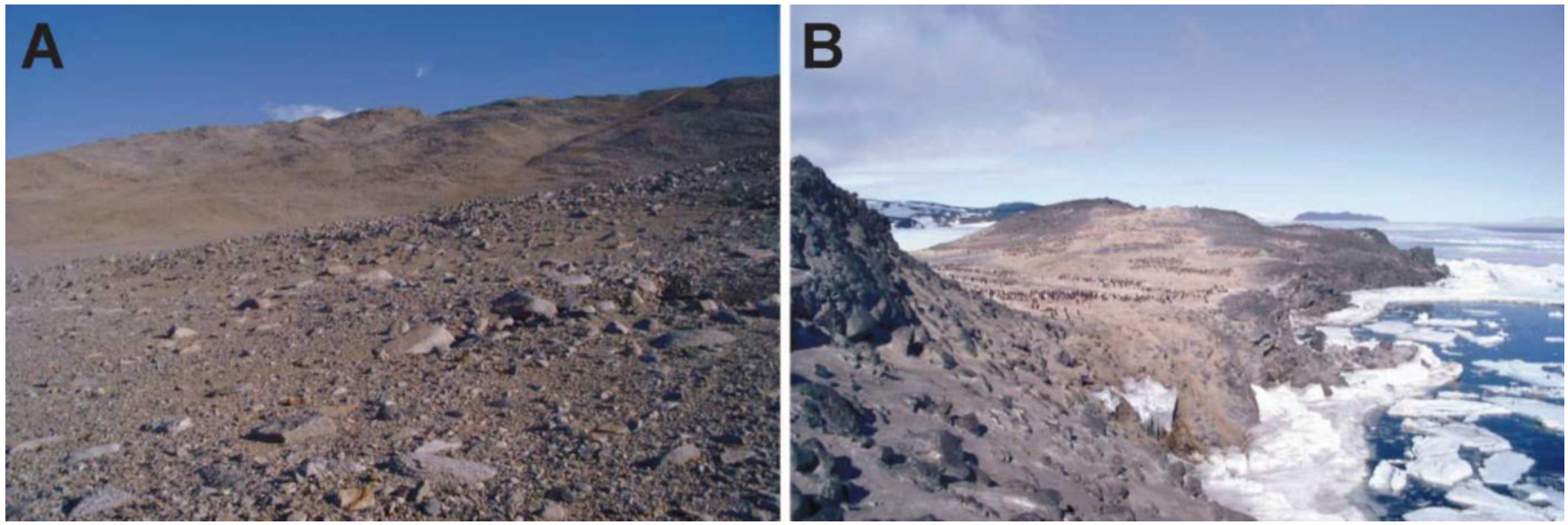

Fig. 1A, B. Representative microbial biotopes sampled for ATP analysis. A Desiccated surface gravels, Miers Valley, Eastern Antarctica; B nutrient-rich ornithogenic soils, Cape Royds Adelie penguin colony, Ross Island

Using data obtained from an ATP standard curve (see Methods section) together with published values (D'Eustachio and Levin 1967; Hamilton and Holm-Hansen 1967; Bancroft et al. 1976; Fairbanks et al. 1984) of ATP bacterium ${ }^{-1}$ (0.16 and 2.25 fg per cell) we calculate that the luminometric data related to cell numbers between approximately $4 \times 10^{4}$ and $5 \times 10^{5}$ cells per 1,000 RLU. From this we calculate that a luminometer reading of 1,000 RLU corresponded to a biomass range of between $3 \times 10^{6}$ and $4 \times 10^{7}$ cells $\mathrm{g}^{-1}$ wet weight (ww). 
Using in situ ATP values, it is calculated that microbial biomass levels in nutrient- and vegetation-rich samples (Cape Bird and Taylor Valley ornithogenic soils, algal-rich flush sites, and bryophyte mats) are in the order of $10^{7}-10^{9}$ cells $\mathrm{g}^{-1}$ ww (Table 1). These values compare well with direct count estimates of Ross

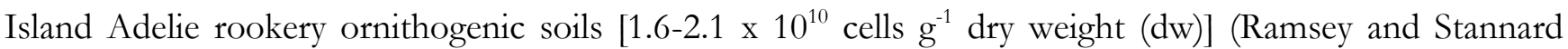
1986) and vegetated fellfield soils $\left(1.6 \times 10^{10} \mathrm{cells} \mathrm{g}^{-1} \mathrm{dw}\right)$ (French and Smith 1986).

Surface mineral soil samples showed surprisingly high ATP content values (828-16,400 RLU; see Table 1). Estimates of microbial biomass (see above) based on these values range from $2.6 \times 10^{6}$ cells $\mathrm{g}^{-1}$ ww to $3.9 \mathrm{x}$ $10^{8}$ cells $\mathrm{g}^{-1} \mathrm{ww}$. Further extensive spot sampling of desiccated surface mineral soils in the Taylor and Miers Valleys gave reliably reproducible RLU values ranging from a few thousands to around 20,000 (data not shown), suggesting that the values shown in Table 1 are broadly representative of Dry Valley mineral soils. These sites (e.g., MV1, TV4.10-12, TV7.1, TV8.1) all possessed very low water contents (0.8\%-6.2\%), within the range reported from Ross Desert sites (Cameron et al. 1970). On the assumption that levels of microbial activity are relatively low due to the low water activity and/ or nutrient status, these values potentially represent unexpectedly high levels of biomass.

\section{Effect of metabolic status}

There is some evidence that ATP levels are influenced by the level of cellular metabolic activity (Fairbanks et al. 1984). In such cases, ATP values obtained from metaboli-cally active biotopes would potentially overestimate cell numbers. The extent of such overestimation is therefore dependent on the quantitative difference in ATP content between metabolically active and inactive cell populations. In monitoring ATP levels in laboratory-grown psychrotol-erant bacterial isolates, we noted that specific ATP levels (ATP titer per unit biomass) were changed little through lag and exponential growth phases (Fig. 2). In addition, periodic field monitoring of in situ ATP levels in Dry Valley gravels over a 87 -h period (three diurnal cycles) where surface temperatures fluctuated from $-1^{\circ}$ to $+16^{\circ} \mathrm{C}$ showed that ATP titers varied by considerably less than one order of magnitude (maximum of 7-fold variation from minimum to maximum RLU values). We therefore conclude that although metabolic activity does influence ATP titers, such fluctuations impact on estimates of calculated microbial cell biomass values by less than an order of magnitude. 


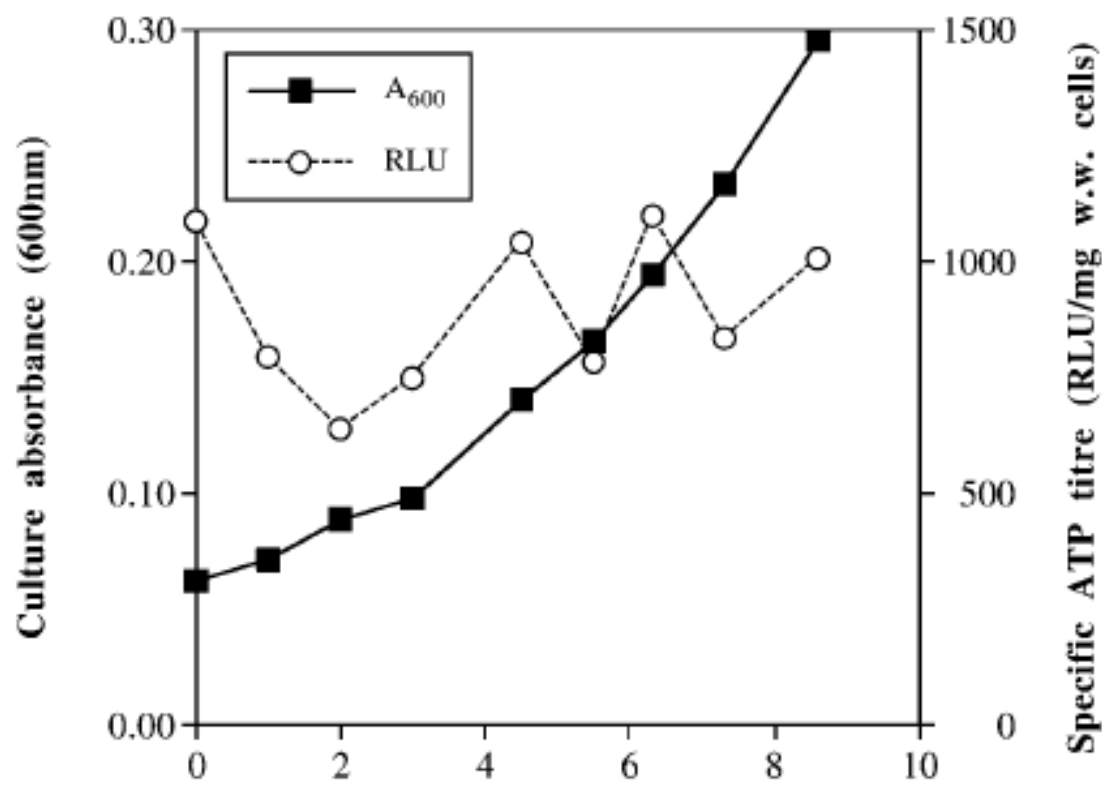

Time (h)

Fig. 2. ATP titers during culture growth. Samples removed at intervals under aseptic conditions were assayed for residual ATP using the systemSURE bioluminescence assay as described in the Methods section. Mean values ( $\mathrm{SD}< \pm 20 \%)$ of triplicate assays are shown

\section{ATP stability}

Alternative explanations might be offered for the high ATP titers in arid Antarctic Dry Valley surface mineral soils. A single previous observation of high ATP levels in arid Antarctic Dry Valley soils (Friedmann et al. 1980) that had been sampled adjacent to cryptoendolithic communities was attributed to the deposition of exfoliated endolithic biomass and the subsequent preservation of extracellular ATP in the frozen desiccated soils. The possibility that exogenous ATP derived from lysed cells and stabilized by the low environmental temperature might significantly affect biomass estimates has previously been considered (Tuovila and La Rock 1987). However, several lines of evidence suggest that this is not the case. Firstly, we investigated a variety of samples by bioluminescence assay in the presence and absence of the cell lysis reagent. In the absence of the lysis reagent, RLU values of little more than background (data not shown) were obtained. Secondly, diNa. ATP solutions added to mineral soils and incubated in situ showed residual half-life values of hours (see, for example, Fig. 3), rather than days or years. The increased soil water content resulting from addition of the ATP solution cannot be attributed as the basis for the rapid degradation, since supplementation of the soil water content over a $1 \%-24 \% \mathrm{gg}^{-1}$ range showed no significant change in ATP half-life $(2.2 \pm 0.7 \mathrm{~h}$ ). We also note that other studies (Roser et al. 1993) have detected little extracellular ATP in continental Antarctic soils. 


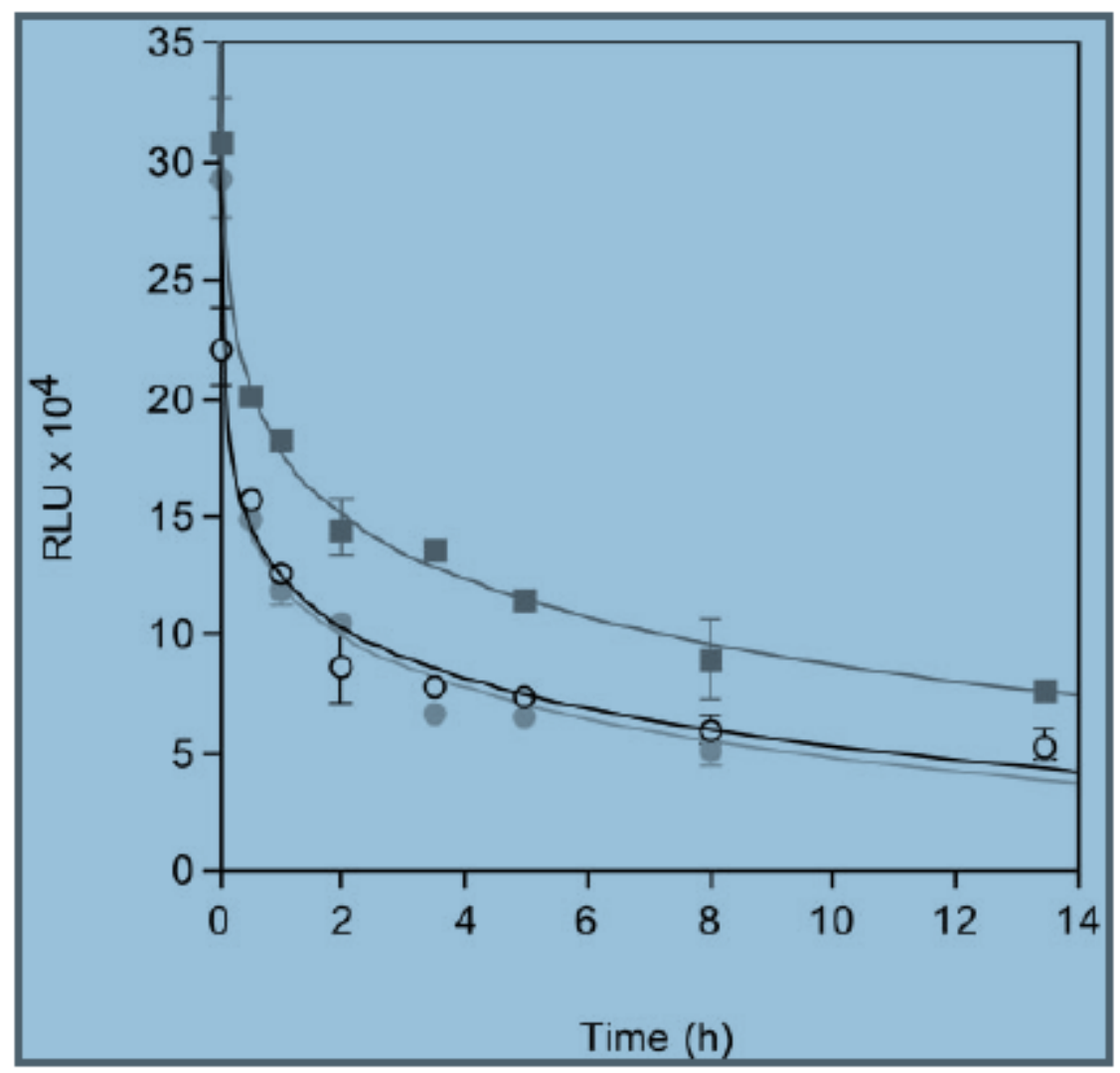

Fig. 3. Stability of exogenous ATP in Ross Desert mineral soils; $200 \mu \mathrm{l}$ aliquots of $0.27 \mathrm{mM}$ diNa.ATP in sterile $\mathrm{dH}_{2} \mathrm{O}$ were added to $10 \mathrm{~g}$ volumes of freshly collected surface mineral soils, mixed by rapid agitation, and incubated at specified temperatures $\left(\boldsymbol{\bullet}, 0^{\circ} ; \mathrm{O}, 7^{\circ} ; \mathbf{\square}, 16^{\circ} \mathrm{C}\right)$. Samples removed at intervals were assayed for residual ATP using the systemSURE bioluminescence assay as described in the Methods section. Mean values and standard deviations of triplicate assays are shown

\section{Eukaryotic cell populations}

Estimates of microbial biomass might also be skewed by the presence of substantial populations of free-living cyanobac-teria, fungi, or algae which have ATP contents that are $10^{2} 10^{3}$-fold higher than bacterial cells (Karl 1980). However, on the basis that direct microscopic analysis of samples showed no filamentous microbial forms or cyanobacteria, and our failure to isolate any yeast colonies on yeast-specific media, we conclude that these organisms, if present, occur in very low numbers. Our conclusion is supported by a number of previous studies (Cameron et al. 1970; Vishniac 1993) that have reported only very low numbers of free-living cyano-bacterial, algal, and fungal populations in Ross Desert sands [e.g., 0-2 $\times 10^{2} \mathrm{cfug}^{-1}$ in surface samples from the Matterhorn Valley (Cameron et al. 1970)]. In addition, it has been reported to us that no cyanobacteria were detected in 51 out of 60 samples of comparable arid gravel taken from the south side of Lake Hoare, Taylor Valley, and examined using epifluorescence microscopy (D. Wynn-Williams, personal communication). We suggest, therefore, that cyanobacterial and eukaryotic cells do not make a significant contribution to the total ATP titers of the soils that we tested. 


\section{Discussion}

The notable discovery from this study is the apparently high level of ATP detected in surface mineral soil samples from Ross Desert sites (e.g., MV1, TV4.10-12, 7.1, 7.6). Calculation of biomass levels from bioluminescence values using a standard value of ATP/cell), gives values ranging from $2.6 \times 10^{6}$ to $4.0 \mathrm{x}$ $10^{8}$ cells $\mathrm{g}^{-1} \mathrm{ww}$, which are four orders of magnitude higher than previously reported microbial populations (Vishniac 1993; Vincent 1988; Vishniac and Mainzer 1972). This reevaluation stems from the use of techniques more suited to the quantification of total biomass. Previous microbiological studies of Antarctic Dry Valley soils have largely employed culture-based quantification methods (Cameron et al. 1970; Vishniac 1993; Vincent 1988), now widely accepted as being poor determinants of true biomass.

An independent calculation of biomass based on extract-able DNA confirms both the general validity of the biolu-minescence method and finding of cell numbers many orders of magnitude higher than previously reported. Using a value of $17 \mathrm{fg}$ DNA per microbial cell (assuming two genomes per cell, with an average genome size of 5 MB: Qiagen Technical literature: http://www.qiagen.com/ catalog/chapter_13/chap13a11.asp), we calculate that cell numbers in the three Ross Desert samples from which DNA was extracted (TV4.10-12; 3.9, 2.5, and $4.6 \mu \mathrm{g}$ DNA g ${ }^{-1} \mathrm{ww}$, respectively) range from $1.5 \times 10^{8}$ to $2.3 \times 10^{8}$ cells $\mathrm{g}^{-1}$ ww. For comparison, a similar calculation for Cape Bird ornithogenic soil samples (CB1.1, $43.0 \mu \mathrm{g} \mathrm{g}^{-1}$; CB3.2, $30.3 \mu \mathrm{g} \mathrm{DNA} \mathrm{g}^{-1}$ ) yields $2.5 \times 10^{9}$ and $1.8 \times 10^{9}$ cells g $^{-1} \mathrm{ww}$, respectively, falling well within the range calculated from biolumi-nescence data (see above).

A second independent confirmation of the validity of biomass determination using ATP analysis is provided by a calculation using extractable phospholipid-fatty acids. A surface soil sample from an adjacent but equally arid Taylor Valley site gave a value of $16 \mu \mathrm{g}$ PL-FA g $\mathrm{g}^{-1}$ soil, which equates to approximately $2 \mathrm{x}$ $10^{8} \mathrm{~g}^{-1} \mathrm{dw}$ soil (Neidhardt et al. 1990).

The demonstration by three independent methods that desiccated Ross Desert mineral soils contain much higher biomass levels than previously thought has extensive implications. While it might be argued that extractable DNA levels are elevated by the accumulation of stable exogenous nucleic acids from lysed cells, it seems improbable that over $99.999 \%$ of extractable DNA (the percentage required to account for a reduction in cell biomass from $10^{8}$ to $10^{4}$ cells g $^{-1}$ soil) is extracellular. Assuming that this is not the case, the presence of a substantial population of "uncultur-able" microorganisms existing in this most extreme environment offers substantial opportunities for further studies of microbial diversity, molecular adaptation, and novel micro-bial bioproducts.

Acknowledgments This project was carried out as part of the Waikato University Antarctic Terrestrial Biology Research Program (DAC) and the BIOTEX-2 Program (NJR) in collaboration with the Natural Resource Ecology Laboratory, Colorado State University. The authors gratefully acknowledge the financial support of the UK Biotechnology and Biological Sciences Research Council, the University of Waikato, Antarctic New Zealand, the Federation of European Biochemical Societies, and the Long Term Ecological Research Program (Professor Diana Wall, Colorado State University), and thank Celsis Instruments, Cambridge, UK for providing the systemSURE bioluminescence monitor. We also wish to express our thanks to Professors Allan Green and Roy Daniel of Waikato University for valuable advice in the preparation of this manuscript. 


\section{References}

Andersen DT, McKay CP, Wharton RA Jr, Rummel JD (1990) An Antarctic research outpost as a model for planetary exploration. J Br Interplanet Soc 43:499-504

Bancroft K, Paul EA, Wiebe WJ (1976) The extraction and measurement of adenosine triphosphate from marine sediments. Limnol Oceanogr 21:473-480

Boyd WL, Staley JT, Boyd JW (1996) Ecology of soil micro-organisms in Antarctica. Antarctic Res Ser 8:125-159

Cameron RE, King J, David CN (1970) Microbiology, ecology and microclimatology of soil sites in dry valleys of South Victoria Land, Antarctica. In: Holdgate M (ed) Antarctic ecology, vol 2. Academic Press, New York, pp 702-716

Claridge GG, Campbell IB (1977) The salts in Antarctic soils, their distribution and relationship to soil processes. Soil Sci 123:337-384

D'Eustachio AJ, Levin EI (1967) Levels of adenosine triphosphate during bacterial growth. Bacteriol Proc 67:119

Davidson CA, Griffith CJ, Peters AC, Fielding LM (1999) Evaluation of two methods for monitoring surface cleanliness - ATP biolumi-nescence and traditional hygiene swabbing. Luminescence 14:33-38

Fairbanks BC, Woods LE, Bryant RJ, Elliot ET, Cole CV, Coleman DC (1984) Limitations of ATP estimates of microbial biomass. Soil Biol Biochem 16:549-558

French DD, Smith VR (1986) Bacterial populations in soils of a sub-Antarctic island. Polar Biol 6:75-82 Friedmann EI (1993a) Extreme environments and exobiology. G Bot Ital 127:369-376

Friedmann EI (1993b) Antarctic microbiology. Wiley-Liss, New York

Friedmann EI, La Rock PA, Brunson JO (1980) Adenosine triphos-phate (ATP), chlorophyll and organic nitrogen in endolithic micro-bial communities and adjacent soils in the dry valleys of southern Victoria Land. Antarct J US 15:164-166

Hamilton RD, Holm-Hansen O (1967) Adenosine triphosphate content in marine bacteria. Limnol Oceanogr 12:319-324

Jenkinson DS, Davidson SA, Powlson DS (1979) Adenosine triphos-phate and microbial biomass in soils. Soil Biol Biochem 11:521-527

Karl DM (1980) Cellular nucleotide measurements and applications in microbial ecology. Microbiol Rev 44:739-796

McKay CP (1993) Relevance of Antarctic microbial ecosystems to exobiology. In: Friedmann IE (ed) Antarctic microbiology. Wiley-Liss, New York, pp 603-614

Neidhardt FC, Ingraham JL, Schaechter M (1990) Physiology of the bacterial cell. Sinauer Associates, Sunderland, MA

Paul EA, Johnson RL (1977) Microscopic counting and adenosine 5"-triphosphate measurement in determining microbial growth in soils. Appl Environ Microbiol 34:263-269

Ramsey AJ, Stannard RE (1986) Numbers and viability of bacteria in ornithogenic soils of Antarctica. Polar Biol 5:195-198

Roser DJ, Seppelt RD, Ashbolt N (1993) Microbiology of ornithogenic soils from the Windmill Islands, Budd Coast, Continental Antarctica: some observations on methods for measuring soil biomass in orni-thogenic soils. Soil Biol Biochem 25:177-183

Siragusa GR, Dorsa WJ, Cutter CN, Perino LJ, Koohmaraie M (1996) Use of a newly developed rapid microbial ATP bioluminescence assay to detect microbial contamination on poultry carcasses. J Biolum Chemilum 11:297-301 
Smith RC, Prezelin BB, Baker KS, et al. (1992) Ozone depletion -ultraviolet radiation and phytoplankton biology in Antarctic waters. Science 255:952-959

Sparling GP, Eiland F (1983) A comparison of methods for measuring ATP and microbial biomass in soils. Soil Biol Biochem 15:227-229

Thompson DC, Craig RM, Bromley AM (1971) Climate and surface heat balance in an Antarctic dry valley. N Z J Sci 14:245-251

Tuovila BJ, La Rock PA (1987) Occurrence and preservation of ATP in Antarctic rocks and its implications in biomass determinations. Geomicrobiol J 5:105-118

Vincent WF (1988) Microbial ecosystems of Antarctica. Cambridge University Press, Cambridge

Vishniac HS (1993) The microbiology of Antarctic soils. In: Friedmann EI (ed) Antarctic microbiology. Wiley-Liss, New York, pp 297-341

Vishniac VW, Mainzer SE (1972) Soil microbiology studied in situ in the dry valleys of Antarctica. Antarct J US 7:88-89

White PL, Wynn-Williams DD, Russell NJ (2000) Diversity of thermal responses of lipid composition in the membranes of the dominant culturable members of an Antarctic fellfield soil bacterial community. Antarct Sci 12:137-146

Wynn-Williams DD (1990) Ecological aspects of Antarctic microbiology. Adv Microbial Ecol 11:71-146

Zwartkruis E, Bettray G, Wilke T (1999) Rapid testing of microbial surface contamination on veal carcasses using ATP bioluminescence. Fleischwirtschaft 79:101-103 